\title{
Kebijakan Deviden, Investasi, Pendanaan, dan Tata Kelola Terhadap Nilai Perusahaan pada Perusahaan LQ45 di Bursa Efek Indonesia Tahun $2014-2017$
}

\author{
Mufidah \\ Fakultas Ekonomi, Universitas Batanghari Jambi, Indonesia
}

\begin{abstract}
Abstrack. This research aimed to examine the influence of dividend policy,investment, funding and, corporate governance to firm value of the Company listed in indeks $L Q 45$ in Indonesia. Firm value was proxied by Tobin's $Q$ (market-based financial performance). Dividend policy was measured by dividend payout ratio, investment was measured by price earning ratio and funding was measured by debt equity ratio, while Corporate governance was identified by number of audit committee. The study used 19 companies as a sample listed on Indonesian Stock Exchange in the period of 2014-2017. The sample was determined by using purposive sampling. This study uses secondary data from financial statements of companies. Classic assumption test in this study include normality test, multicollinearity test, heterocedasticity test and autocorrelation test. Analysis of data using multiple linear regression analysis, $t$ test, $F$ test, and test the coefficient of determination. Analysis of data using multiple linear regression analysis with SPSS 22. The results showed only dividend policy had positive effect on firm value.
\end{abstract}

Keywords: Dividend Policy, funding, firm value, Investment

\section{PENDAHULUAN}

Salah satu kinerja perusahaan diukur melalui nilai perusahaan. Nilai perusahaan dapat diukur dari berbagai aspek diantaranya adalah melalui nilai buku (book value) dan nilai pasar (market value) ekuitas. Nilai buku ekuitas adalah nilai ekuitas yang didasarkan pada pembukuan perusahaan. Sedangkan nilai pasar ekuitas adalah nilai ekuitas berdasarkan harga pasar yang sering dikaitkan dengan harga saham perusahaan di pasar modal. Salah satu alternatif pengukuran kinerja perusahaan yang dapat digunakan adalah dengan menggabungkan antara nilai buku dan nilai pasar ekuitas, yaitu melalui rasio Tobin's Q. Rasio ini diukur dari nilai pasar ekuitas ditambah nilai buku total kewajiban kemudian dibagi dengan nilai buku total aset. Tobin's Q merupakan ukuran yang lebih teliti karena memberikan gambaran yang tidak hanya pada aspek fundamental, tetapi juga sejauh mana pasar menilai perusahaan dari berbagai aspek yang dilihat oleh pihak luar termasuk investor (Hastuti, 2005). Semakin besar nilai Tobin's Q menunjukkan bahwa perusahaan memiliki prospek pertumbuhan yang baik. Nilai perusahaan dapat ditingkatkan dengan meningkatkan kinerja perusahaan. Salah satu caranya adalah dengan menerapkan praktik tata kelola perusahaan yang baik. Dalam penelitian ini, nilai perusahaan diukur dengan nilai Tobin's Q.

Kebijaksanaan dividen (dividen policy) menentukan berapa banyak dari keuntungan harus dibayarkan kepada pemegang saham dan berapa banyak yang harus ditanam kembali di dalam perusahaan. Semakin besar dividen yang dibagikan kepada pemegang saham, maka kinerja perusahaan akan dianggap baik, dan pada akhirnya penilaian terhadap perusahaan akan semakin baik pula. Dengan demikian dividen memiliki peran yang penting dalam menjelaskan nilai perusahaan. Keputusan investasi berhubungan langsung dengan perusahaan, dalam artian bahwa keputusan investasi erat kaitannya dengan kegiatan investasi yang dilakukan oleh perusahaan. Keputusan investasi berkaitan dengan proses pemilihan satu atau lebih alternatif investasi yang dinilai menguntungkan dari sejumlah alternatif investasi yang tersedia bagi perusahaan. Keputusan investasi dapat mempengaruhi nilai perusahaan karena dengan komposisi investasi yang baik akan dapat menarik investor untuk berinvestasi pada perusahaan tersebut. Dengan demikian, semakin tinggi keputusan investasi yang ditetapkan oleh perusahaan maka semakin tinggi kesempatan perusahaan dalam memperoleh return atau tingkat pengembalian yang besar. (Adisetiawan, 2018)

Aktivitas Bisnis didanai dengan kewajiban atau ekuitas, atau kedua-duanya. Kewajiban merupakan utang untuk mendapatkan pendanaan yang membutuhkan pembayaran di masa yang akan depan dalam bentuk uang, jasa atau asset lainnya. Perusahaan dinilai berisiko apabila memiliki porsi hutang yang besar dalam struktur modalnya. Namun apabila hutang tersebut dapat menghasilkan keuntungan maka hutang tersebut akan meningkatkan nilai perusahaan. Auditor merupakan satu sumber keyakinan dalam identifikasi 
dan pengukuran kewajiban. Jika kewajiban dinyatakan lebih rendah dari yang seharusnya, auditor harus mewaspadai penyajian laba lebih tinggi dari yang seharusnya karena beban yang lebih rendah atau ditangguhkan. Oleh karena itu adanya komite audit dan pergantiannya yang dilakukan secara berkala membuat fungsi pengawasan perusahaan lebih terjaga dan dapat terciptanya tata kelola yang baik, yang pada akhirnya dapat menaikkan nilai perusahaan. (Adisetiawan, 2017)

Perusahaan yang dipilih untuk menjadi obyek penelitian ini adalah perusahaan yang masuk dalam indeks saham LQ45 berturut-turut untuk periode 2014 - 2017. Pemilihan perusahaan berdasarkan indeks saham LQ45 ini karena perusahaan ini telah dinilai sebagai perusahan yang besar yang mudah memperoleh dana dari pasar bursa yang umumnya memiliki pembagian dividen yang besar dibandingkan perusahaan yang lebih kecil. Rata-rata dividend payout ratio (DPR), Price Earning Ratio (PER) debt to equity (DER) dan Nilai Perusahaan seperti terlihat dalam Tabel 1 berikut ini:

\section{Tabel 1}

\section{Rata-rata Deviden Payout Ratio, Price Earning Ratio, dan Debt to Equity Ratio pada Industri yang} Tergabung dalam LQ45 Periode 2014 - 2017

\begin{tabular}{|c|c|c|c|c|c|}
\hline \multirow{2}{*}{ Variabel } & \multicolumn{4}{|c|}{ Tahun } & \multirow{2}{*}{ Rata-rata } \\
\hline & 2014 & 2015 & 2016 & 2017 & \\
\hline DPR & 39.91 & 41.48 & 42.53 & 51.20 & 43.78 \\
\hline PER & 21.88 & 17.27 & 20.98 & 19.88 & 20.00 \\
\hline DER & 3.12 & 2.05 & 1.87 & 1.90 & 2.24 \\
\hline Nilai Perusahaan & 4.02 & 3.23 & 3.40 & 3.48 & 3.53 \\
\hline
\end{tabular}

Sumber : Data diolah

Tabel 1 diatas, terlihat bahwa rata-rata tingkat pembayaran deviden selama 4 (empat) tahun mengalami kenaikan berturut-turut dengan rata-rata yaitu 43,78\%. Namun hal ini tidak sebanding dengan nilai perusahaan yang dihitung dengan rumus tobins Q yang mengalami kenaikan rata-rata di tahun 2014 dan kemudian menurun di tahun 2015 dan naik kembali di tahun selanjutnya Hal ini menunjukkan adanya indikasi pengaruh dari kebijakan deviden yang semakin naik dan pendanaan yang semakin turun. Pengendalian biaya lebih lanjut akan memungkinkan perusahaan yang termasuk indeks LQ45 untuk terus meningkatkan profitabilitas dan melebihi standar industri sehingga tingkat dividen payout $(43,78 \%)$ menjadi cukup tinggi. Ini menandakan bahwa industri ini memilih untuk membayarkan sejumlah besar dari labanya. Berdasarkan Penelitian-penelitian sebelumnya seperti penelitian Sofia dan farida (2017) bahwa kebijakan deviden dan kebijakan hutang tidak berpengaruh terhadap nilai perusahaan sedangkan keputusan investasi berpengaruh terhadap nilai perusahaan. Penelitian ini bertujuan untuk mengetahui apakah kebijakan deviden, investasi, pendanaan dan tata kelola berpengaruh secara simultan dan parsial terhadap nilai perusahaan pada perusahaan yang tergabung pada LQ45 di Bursa Efek Indonesia Periode 2014-2017.

\section{Landasan Teori dan Hipotesis \\ Nilai Perusahaan}

Tobin's Q memiliki manfaat tersendiri dalam merefleksikan nilai perusahaan dan potensial profitabilitas perusahaan dimasa mendatang (Ruan et al. 2011). Menurut Sulong dan Nor (2008) alasan yang mendasari penggunaan Tobin's Q sebagai proksi nilai perusahaan adalah belum adanya persetujuan umum mengenai ukuran yang pasti dalam mengukur nilai perusahaan, sehingga Tobin's Q dianggap dapat digunakan sebagai alternatif proksi nilai perusahaan. Alasan lainnya adalah bahwa perhitungan Tobin's Q yang sederhana dan telah digunakan secara luas pada berbagai penelitian mengenai nilai perusahaan di mancanegara. Tobin's Q diukur dengan perhitungan nilai pasar ekuitas ditambah dengan nilai buku utang jangka pendek dan nilai buku utang jangka panjang dibagi dengan total asset (Kumar dan Singh, 2013).

\section{Kebijakan Deviden Payout Ratio}

Prihantoro (2003), mendefinisikan kebijakan deviden sebagai kebijakan yang berhubungan dengan pembayaran deviden kepada pihak perusahaan. Jika manajemen meningkatkan porsi laba perlembar saham yang dibayarkan sebagai deviden, maka mereka dapat meningkatkan kesejahteraan para pemegang saham. 
Hal ini menyarankan bahwa keputusan jumlah deviden yang di bayarkan merupakan hal yang sangat penting.

\section{Keputusan Investasi}

Keputusan investasi adalah penanaman modal dengan harapan akan memperoleh keuntungan dimasa yang akan datang (Jogiyanto, 2010). Keputusan investasi berhubungan langsung dengan perusahaan, dalam artian bahwa keputusan investasi erat kaitannya dengan kegiatan investasi yang dilakukan oleh perusahaan. (Sudana, 2011) menyatakan bahwa keputusan investasi berkaitan dengan proses pemilihan satu atau lebih alternatif investasi yang dinilai menguntungkan dari sejumlah alternatif investasi yang tersedia bagi perusahaan.Teori signaling yang menyatakan pengeluaran investasi memberikan sinyal positif tentang pertumbuhan perusahaan dimasa yang akan datang, sehingga meningkatkan harga saham sebagai indikator nilai perusahaan. Hal ini sependapat dengan (Jogiyanto, 2010) yang menyatakan bahwa informasi yang dipublikasi sebagai suatu pengumuman akan memberikan signal bagi investor dalam pengambilan keputusan investasi. Jika pengumuman tersebut mengandung nilai positif, maka akan banyak investor yang berinvestasi keperusahaan.

\section{Komite Audit}

Komite audit ini merupakan usaha perbaikan terhadap cara pengelolaan perusahaan terutama cara pengawasan terhadap manajemen perusahaan, karena akan menjadi penghubung antara manajemen perusahaan dengan dewan komisaris maupun pihak ekstern lainnya. Hasil yang serupa dengan hasil penelitian Obradovich dan Gill (2013) dan Rouf (2011), serta Tornyeva dan Wereko (2012) dimana dinyatakan bahwa variabel komite audit memberi pengaruh signifikan positif terhadap nilai perusahaan.

\section{Hipotesis}

Diduga kebijakan deviden, investasi, pendanaan dan tata kelola berpengaruh secara simultan dan parsial terhadap nilai perusahaan pada perusahaan yang tergabung pada LQ45 di Bursa Efek Indonesia Periode 2014-2017.

\section{METODE PENELITIAN}

Jenis data yang digunakan dalam penelitian ini adalah data sekunder. Metode pengumpulan data yang digunakan yaitu metode dokumentasi yang merupakan metode pengumpulan data dengan cara mempelajari catatan-catatan atau dokumen. Data yang digunakan dalam penelitian ini diperoleh dari laporan keuangan perusahaan yang termasuk dalam perusahaan yang termasuk dalam indeks LQ45 yang dipublikasikan oleh Bursa Efek Indonesia (BEI) melalui situs www.idx.co.id dan annual report perusahaan yang diambil dari website masing-masing perusahaan.

\section{Populasi dan Sampel}

Populasi pada penelitian ini adalah perusahaan yang terdaftar di BEI dan tercantum dalam indeks LQ45 dari tahun 2014 sampai tahun 2017. Selain penilaian atas likuiditas, seleksi atas saham-saham tersebut juga mempunyai kapitalisasi pasar yang cukup besar. Sedangkan sampel dalam penelitian ini diambil dengan menggunakan metode purposive sampling, yaitu teknik penentuan sampel dengan pertimbangan tertentu. Adapun kriteria yang diambil menjadi sampel adalah perusahaan yang terdaftar di LQ45 secara berturut-turut dari tahun 2014 sampai tahun 2017 dan membayarkan devidennya secara berturut-turut dari tahun 2014 sampai tahun 2017. Tabel 2 berikut di bawah ini adalah nama-nama perusahaan yang menjadi sampel penelitian.

\section{Pengukuran Variabel}

Variabel yang digunakan dalam penelitian ini, terdiri dari variabel independen, dan variabel dependen. Variabel independen dalam penelitian ini adalah kebijakan deviden yang diproksikan dengan deviden payout ratio (DPR), kebijakan investasi yang diproksikan dengan price earning ratio (PER), Pendanaan yang diproksikan dengan debt equity ratio (DER) dan tata kelola yang diprosikan dengan komite 
audit. komite audit diukur dengan banyaknya anggota komite audit yang dimiliki perusahaan, sedangkan. Variabel dependen dalam penelitian ini adalah nilai perusahaan yang diproksikan dengan Tobin's Q. Tobin's $\mathrm{Q}$ diukur dengan menjumlahkan nilai pasar saham dan nilai buku total hutang kemudian dibagi dengan nilai buku total aset.

\section{Analisis Data}

Metode analisis data yang dipergunakan dalam penelitian ini adalah metode analisis data kuantitatif yang diolah dengan program komputer Statistical Package For Social Science (SPSS) 22. Metode analisis data yang dilakukan pada penelitian ini meliputi statistik deskriptif, uji asumsi klasik, dan kemudian dilakukan pengujian hipotesis. Pengujian hipotesis dalam penelitian ini menggunakan analisis regresi linier berganda. Model persamaan regresi liner berganda yang dibangun dalam penelitian ini adalah:

Nilai $=\alpha+\beta_{1}$. DPR $_{\text {it }}+\beta_{2}$. PER $_{\text {it }}+\beta_{3}$. DER $_{\text {it }}+\beta_{4}$. Komite $_{i t}+\mathrm{e}$.

Keterangan: Nilai : Nilai Perusahaan Tobins Q; DPR : Deviden payout ratio; PER : Price Earning ratio; DER : Debt Equity Ratio; Komite : Jumlah Komite audit; $\alpha$ : Konstanta; $\beta_{1}-\beta_{4}$ : Koefisien Regresi; e : Error

\section{HASIL DAN PEMBAHASAN}

Tabel 2

Model Summary

\begin{tabular}{|l|l|l|l|l|l|}
\hline Model & R & R Square & Adjusted R Square & Std. Error of the Estimate & DW \\
\hline 1 & $.448^{\mathrm{a}}$ & .200 & .155 & .76053 & .792 \\
\hline
\end{tabular}

Sumber: data olahan

Penelitian ini model persamaan regresi linier berganda dengan data panel yang disusun untuk mengetahui pengaruh kebijakan deviden, investasi dan pendanaan serta tata kelola (sebagai variabel independen) terhadap nilai perusahaan (sebagai variabel dependen) hasil uji regresi berganda dapat dilihat pada tabel 3 berikut ini:

Tabel 3

Hasil Uji Regresi Berganda

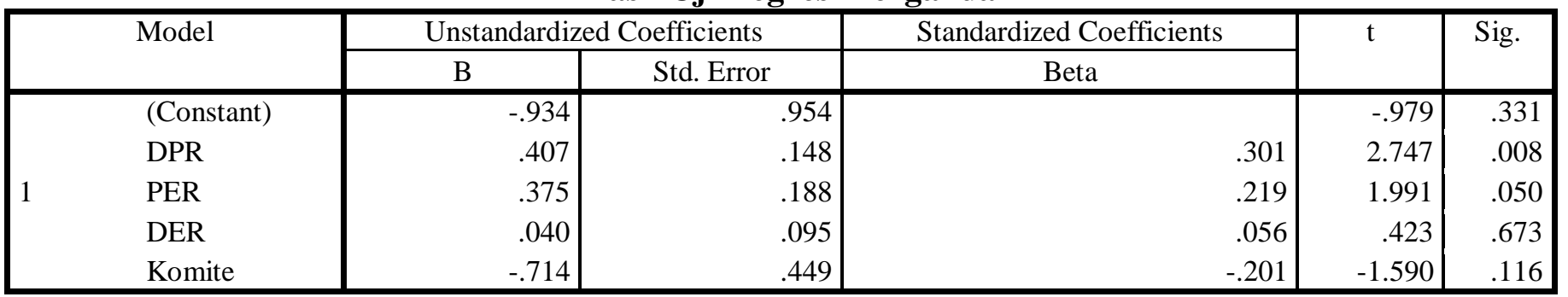

Sumber: data olahan

Berdasarkan hasil analisis regresi berganda dengan data panel pada tabel 3 di atas dapat diperoleh koefisien untuk variabel bebas DPR $=0,407, \mathrm{PER}=0,375, \mathrm{DER}=0.040$ dan Komite $=-0.714$ konstanta sebesar -0.934 sehingga model persamaan regresi yang diperoleh:

$\mathrm{Y}_{\text {it }}=-0.934+0,407 \mathrm{X}_{1 \mathrm{it}}+0,375 \mathrm{X}_{2 \mathrm{it}}+0.040 \mathrm{X}_{3 \mathrm{it}}-0.714 \mathrm{X}_{4 \mathrm{it}}+\mu$

Dimana : Y = Tobin's Q; $\beta_{0}=$ konstanta; $\beta_{1}=$ koefisien Regresi Deviden Payout Ratio; $\beta_{4}=$ koefisien Regresi komite auadit; $X_{1}=$ Deviden Payout Ratio; $X_{4}=$ Komite Audit (KA); $\beta_{2}=$ koefisien Regresi Price Earning Ratio $\mathrm{B}_{3}=$ koefisien Regresi DER; $\mathrm{X}_{2}=$ Price Earning Ratio; $\mathrm{X}_{3}=$ Debt Equity Ratio; $\mathrm{i}=$ Unit cross section; $\mathrm{t}=$ Periode waktu; $\mu=$ error. Menggunakan tingkat keyakinan $95 \%$ untuk $\alpha=5 \%$ dengan derajat kebebasan $(\mathrm{df})=71$ maka $\mathrm{t}_{\text {tabel }}$ diperoleh sebesar 1,99394 .

\section{Uji Hipotesis}


Pengujian hipotesis dalam penelitian ini dilakukan dengan menggunakan teknik analisis regresi linier berganda. Peneliti menggunakan $\alpha=5 \%$ untuk menilai signifikansi hubungan antara setiap variabel. Uji $F$ digunakan untuk mengetahui apakah variabel independen yang terdapat dalam persamaan regresi secara bersama-sama mempengaruhi variabel dependen. Hasil perhitungan uji $\mathrm{F}$ untuk model regresi yang diteliti dapat dilihat pada tabel 4 berikut :

\begin{tabular}{|c|c|c|c|c|c|c|}
\hline \multicolumn{7}{|c|}{$\begin{array}{c}\text { Tabel } 4 \\
\text { ANOVA }^{\mathrm{a}}\end{array}$} \\
\hline Model & & Sum of Squares & Df & Mean Square & $\mathrm{F}$ & Sig. \\
\hline 1 & $\begin{array}{l}\text { Regression } \\
\text { Residual } \\
\text { Total }\end{array}$ & $\begin{array}{l}10.289 \\
41.067 \\
51.356\end{array}$ & $\begin{array}{l}4 \\
71 \\
75\end{array}$ & $\begin{array}{l}2.572 \\
.578\end{array}$ & 4.447 & $.003^{b}$ \\
\hline
\end{tabular}

Sumber: data olahan

Uji Anova atau $\mathrm{F}$ test sebesar 4.447 dengan tingkat probabilitas 0.000 (signifikan), karena probabilitas jauh lebih kecil daripada 0.05 yaitu 0.003 maka model regresi dapat digunakan untuk memprediksi Y (nilai perusahaan) atau dapat dikatakan Tingkat pembayaran deviden, investasi dan pendanaan serta tata kelola secara bersama-sama berpengaruh terhadap nilai perusahaan pada perusahaan LQ 45 yang terdaftar di Bursa Efek Indonesia (BEI) periode 2014 - 2017. Analisis determinasi dilakukan untuk mengetahui persentase sumbangan pengaruh variabel bebas terhadap variabel terikat. Berdasarkan tabel 7 di atas, diperoleh nilai $R$ Square yaitu sebesar 0.200. Hal ini menunjukkan bahwa besar pengaruh kebijakan deviden, investasi dan pendanaan serta ukuran komite audit terhadap nilai perusahaan adalah sebesar 20.\% sedangkan sebesar 80\% dipengaruhi oleh faktor lain diluar penelitian ini. Tabel 4 hasil uji parsial (t- test), variabel deviden payout ratio (DPR) memiliki pengaruh signifikan positif terhadap nilai perusahaan. Hal ini dapat dilihat dari probabilitas signifikansi untuk DPR sebesar 0.008 yang lebih kecil daripada 0.05 dan karena nilai t statistik > t tabel. Oleh karena itu hipotesis $\mathrm{H} 1_{\mathrm{a}}$ diterima. Hasil penelitian ini tidak sejalan dengan penelitian Sofia dan Farida (2017), uji parsial (t- test), variabel Price Earning Ratio (PER) tidak memiliki pengaruh signifikan terhadap nilai perusahaan. Hal ini dapat dilihat dari nilai $t$ statistic lebih kecil daripada $\mathrm{t}$ tabel. Oleh karena itu hipotesis $\mathrm{H} 2$ a ditolak. Hasil penelitian sejalan Hasil penelitian ini didukung oleh tetapi penelitian ini tidak sejalan dengan penelitian Sofia dan Farida (2017). Uji parsial ( $t$ - test), variabel debt to equity ratio ( DER) tidak memiliki pengaruh signifikan terhadap nilai perusahaan. Hal ini dapat dilihat dari nilai t statistik lebih kecil daripada t tabel. Oleh karena itu hipotesis $\mathrm{H}_{\mathrm{a}}$ ditolak. Hasil penelitian ini sejalan dengan penelitian Sofia dan Farida (2017). Hasil uji parsial didapatkan bahwa komite audit (Komite) tidak berpengaruh signifikan terhadap nilai perusahaan. Dilihat dari probabilitas signifikansi untuk ukuran komite audit sebesar 0.116 dimana probabilitas jauh lebih besar daripada 0.05 dan nilai t statistik lebih kecil daripada $t$ tabel. Oleh karena itu hipotesis $\mathrm{H}_{a}$ ditolak Menurut F. Antonius Alijoyo, seorang narasumber dari FCGI menyatakan bahwa efektivitas komite audit dapat terbentuk apabila komite audit tersebut independen, transparan, memiliki akuntabilitas yang tinggi, adil, dan memiliki charter komite audit.konsisten dengan Komite audit memiliki pengaruh signifikan positif terhadap nilai perusahaan yang bergerak di sektor keuangan yang terdaftar di Bursa Efek Indonesia. Hasil ini konsisten dengan penelitian Babatunde dan Olaniran (2009). Penelitian ini bertolak belakang dengan penelitian yang dilakukan oleh Obradovich dan Gill (2013), Rouf (2011), serta Tornyeva dan Wereko (2012).

\section{SIMPULAN}

Berdasarkan hasil analisis data yang telah dilakukan, dapat ditarik kesimpulan bahwa kebijakan deviden yang diproksikan dengan tingkat pembayaran deviden, investasi yang diproksikan dengan price earning ratio dan pendanaan yang diproksikan dengan debt to equity ratio dan tata kelola yang diproksikan jumlah komite audit mempunyai pengaruh secara bersama-sama atau simultan terhadap nilai perusahaan. Sedangkan secara parsial hanya kebijakan deviden yang mempunyai pengaruh positif dan signifikan 
terhadap nilai perusahaan. Investor lebih berminat pada perusahaan yang memiliki pembayaran deviden cara berkelanjutan yang pada akhirnya juga berdampak pada peningkatan nilai perusahaan.

\section{DAFTAR PUSTAKA}

Adisetiawan, R., 2018, Does Stock Split Influence to Liquidity and Stock Return? (Empirical Evidence in the Indonesian Capital), Asian Economic and Financial Review, 8(5), 682-690

Adisetiawan, R., 2017, Globalisasi Pasar Modal Dunia dan Pengaruhnya Terhadap Pasar Modal Indonesia, Ekonomis: Journal Economics and Business, 1(1), 10-17

Hastuti, D., T., (2005). Hubungan antara good corporate governance dan struktur kepemilikan dengan kinerja keuangan. Simposium Nasional Akuntansi VIII, Solo. 475-490.

Jogiyanto. 2010. Teori Portofolio dan Analisis Investasi. Edisi ketujuh : BPFE. Yogyakarta

Kumar, N., \& Singh, J. P. 2013. Effect of Board Size and Promoter Ownership on Firm Value: Some Empirical Findings from India. Corporate Governance: The International Journal of Business in Society, Vol. 13 (1), 88-98.

Obradovich, J., \& Gill, A., 2013. The Impact of Corporate Governance and Financial Leverage on the Value of American Firms. International Research Journal of Finance and Economics, ISSN 1450-2887 Issue 91, 1-14.

Prihantoro. 2003. Estimasi Pengaruh Devidend Payout Ratio Pada Perusahaan Publik di Indonesia, Jurnal Ekonomi dan Bisnis, No. 1 Jilid 8.

Rouf, A., 2011. The Relationship between Corporate Governance and Value of the Firm in Developing Countries: Evidence from Bangladesh. The International Journal of Applied Economics and Finance Vol. 5 (3), 237-244.

Ruan, W., Tian, G., \& Ma, S. 2011. Managerial Ownership, Capital Structure and Firm Value: Evidence from China's Civilian-run Firms. Australasian Accounting, Business and Finance Journal, Vol. 5 (3), 73-92.

Sudana, I Made. 2011. Manajemen Keuangan Perusahaan Teori \& Praktik. Jakarta: Erlangga

Tornyeva, K., \& Wereko, T., 2012. Corporate Governance and Firm Performance: Evidence from the Insurance Sector of Ghana. European Journal of Business and Management Vol. 4 (13), 95-112. 